DOI 10.4467/2543733XSSB.17.037.8335

KATARZYNA FIJOŁEK

Instytut Nauk Politycznych i Stosunków Międzynarodowych

Uniwersytet Jagielloński

\title{
RUCH NA RZECZ PRAW I SWOBÓD. POMIĘDZY PARTIĄ LIBERALNĄ A REPREZENTACJĄ MNIEJSZOŚCI TURECKIEJ W BULGARII
}

Słowa kluczowe: mniejszość turecka, DPS, Ruch na rzecz Praw i Swobód, partia etniczna, partia liberalna, relewancja partii politycznych, małe partie

Obserwując Bułgarię, która 27 lat temu wkroczyła w etap przemian ustrojowych, można uznać, że zmiany w sferze tamtejszego życia politycznego charakteryzują się, podobnie jak w innych państwach bloku socjalistycznego, typową postkomunistyczną dynamiką i nietrwałością form politycznych. Wiele ugrupowań pojawiało się, by następnie po kilku latach ulec marginalizacji. Te, którym udało się przetrwać, wielokrotnie musiały zmodyfikować swoją linię programową, aby odpowiadała aktualnym trendom i potrzebom elektoratu. Nierzadko wiązało się to z podziałami formacji bądź koniecznością koalicji z innymi ugrupowaniami. W tym gronie można wyróżnić partie takie jak: Bułgarska Partia Socjalistyczna (BSP ${ }^{1}$, bułg. Българска социалистическа партия), Sojusz Sił Demokratycznych (SDS, bułg. Съюз на демократичните сили) ${ }^{2}$ czy Ruch na rzecz Praw i Swobód (DPS, bułg. Движение за права и свободи). Ewolucja programowa ostatniego będzie przedmiotem tej analizy.

Podczas przemówienia otwierającego IX Krajową Konwencję Ruchu na rzecz Praw i Swobód w 2016 r. Junal Lutwi ${ }^{3}$ dokonał podsumowania działalności partii z perspektywy minionych lat. Polityk podkreślał między innymi liberalną naturę ugrupowania:

(...)Od tego momentu minęło dwadzieścia sześć lat, kiedy DPS umocował się jako trzecia siła polityczna w skali ogólnokrajowej. W czasach trudnych przemian ustrojowych Ruch na rzecz

${ }^{1}$ Na potrzeby niniejszej publikacji autorka będzie stosować bułgarskie skróty partii: BSP, SDS, DPS, itd. Skróty polskie mogą sprawiać wrażenie mało czytelnych.

2 Od 2013 r. w koalicji z innymi partiami w ramach Bloku Reformatorskiego (bułg. Реформаторски блок).

3 Junal Lutwi - ur. 1944, bułgarski polityk, jeden z założycieli Ruchu na rzecz Praw i Swobód.

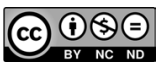


Praw i Swobód miał jasne priorytety dotyczące kształtu polityki wewnętrznej i międzynarodowej oraz przekonanie o wspólnym i bezinteresownym dążeniu do ich realizacji.(...) Szanowni Delegaci, DPS to największa liberalna partia w Bułgarii! Od momentu swojego założenia partia idzie drogą zasad i wartości liberalizmu: praw człowieka, prymatu prawa, praw mniejszości oraz wolności słowa. Nasza partia zdołała zdobyć pozycję jedynej siły politycznej, bez zgody której nie zostanie uchwalona ani jedna narodowa kwestia dotycząca bułgarskiego społeczeństwa dziś i jutro ${ }^{4}$.

Podobne słowa budzą jednak głęboki sprzeciw politycznych konkurentów Ruchu na rzecz Praw i Swobód, bowiem najczęściej formułowany zarzut pod adresem partii to jej etniczny charakter. Do dzisiaj środowiska skrajnej prawicy krytykują DPS za realizowanie interesów Turcji lub mniejszości tureckiej w Bułgarii ${ }^{5}$. To zaś poważne oskarżenie z uwagi na art. 11.4 Bułgarskiej Konstytucji z 12 lipca 1991 r. ${ }^{6}$, który ostrzega:

Nie można tworzyć partii politycznych na podstawie przynależności etnicznej, rasowej lub wyznaniowej, jak również partii, które stawiają sobie za cel siłowe przejęcie władzy państwowej ${ }^{7}$.

Historia tego zapisu jest związana z początkiem przemian, gdy podczas pierwszych wyborów demokratycznych w 1990 r. DPS zdobył aż 23 miejsca w Wielkim Zgromadzeniu Narodowym ${ }^{8}$. Obawiając się wpływu etnicznych Turków w parlamencie, Sojusz Sił Demokratycznych postanowił wprowadzić powyższe ograniczenie. Debata nad nową konstytucją przebiegała niezwykle burzliwie. Posłowie Ruchu na znak protestu zbojkotowali głosowanie nad przyjęciem nowej ustawy zasadniczej. Nie miało to jednak znaczenia, gdyż konstytucja została uchwalona 12 lipca 1991 r. przez 309 deputowanych. Tym samym Bułgaria stała się pierwszym państwem w regionie Europy Środkowo-Wschodniej, które uchwaliło nową ustawę zasadniczą w zgodzie z zasadami demokracji ${ }^{9}$. Tymczasem przyszłość młodego ugrupowania, które w większości reprezentowali Turcy stała się zagrożona ${ }^{10}$. Chociaż ostatecznie partia przetrwała ten kryzys,

${ }^{4}$ W oryginale: „От тогава изминаха 26 години в които ДПС се утвърди като трета политическа сила в политическия спектър на страната. В годините на трудния преход Движение за права и свободи имаше ясни вътрешнополитически и геополитически приоритети, убедено и всеотдайно да работи в тяхната реализация.(...) ДПС е най-голяма либерална политическа партия, Уважаеми делегати. От свойто основание ДПС следва основните принципи и ценности на либерализма: правата на човека, върховенство на закона, правата на малцинствата, свободата на словото. Наща партя успя да се утвърди като една от политическите парти без която не може да бъде решен нито един национален въпрос касаещ българското общество - днес и утре” (tłum. K. Fijołek) [za:] Изказване на Юнал Лютви от 24.04.2016, За ДПС, Движение за права и свободи - официален сайт, http://www.dps.bg/bg/za-dps/ix-ta-nk-na-dps.html (dostęp 11.12.2016).

5 Zob. И. Хри с то ва, ДПС доказва, че е турска партия [w:] Десант, http://www.desant.net/show-news/34612/ (dostęp 05.01.2017).

$6 \quad$ Konstytucja Republiki Bułgarii z dnia 12 lipca 1991, http://libr.sejm.gov.pl/tek01/txt/konst/bulgaria2011.html (dostęp, 07.06.2017).

7 Art.11.4, Ibidem (dostęp 07.06.2017).

${ }^{8}$ R. Woźn i c a, Bułgarska polityka wewnętrzna a proces integracji z Unią Europejska, Kraków 2012, s. 57.

${ }_{9}$ Więcej na temat bułgarskiej konstytucji zob. J. Karp, M. Grzybow s ki, System konstytucyjny Butgarii, Warszawa 2002.

${ }^{10}$ И. Бае в а, Българските турци в годините на прехода (1989-2007), [w:] Толерантният националист. Паметен сборник от приятелите на Стайко Трифонов, София 2009, s. 398. 
zapis konstytucyjny odbił się na jej wizerunku, tworząc poważny argument w przyszłych zatargach politycznych.

Należy postawić pytanie, jaką partią jest współcześnie Ruch na rzecz Praw i Swobód? W jaki sposób sklasyfikować ugrupowanie, które z jednej strony przedstawia się jako reprezentant całego społeczeństwa, z drugiej zaś organizuje wiece wyborcze w języku tureckim, zrozumiałym tylko dla części wyborców ${ }^{11}$ ? Czy droga zasad i wartości liberalizmu, o której wspominał w przemówieniu Junal Lutwi, nie stanowi tylko gry politycznych pozorów? Niezależnie od zapewnień, zawartych w powyższym przemówieniu, trudno uwierzyć, że DPS niezmiennie podąża tą samą drogą. Kluczowym argumentem w tej sprawie jest bowiem kontrowersyjny zapis Konstytucji. Celem niniejszej publikacji jest ukazanie, w jaki sposób ewoluowała partia Ruch na rzecz Praw i Swobód. Podstawą analizy porównawczej będą dokumenty Ruchu, w tym jego materiały promocyjne (prasa partyjna, przemówienia) $)^{12}$. Jako wsparcie przy próbie zaklasyfikowania posłuży nam publikacja Hanny Herzog Minor Parties: The Relevancy Perspective ${ }^{13}$, w której autorka analizuje rolę małych partii w izraelskim systemie politycznym z perspektywy teorii relewancji partii Sartoriego ${ }^{14}$. Według jej kryteriów nie wszystkie małe partie (ang. minor parties) mogą być uznawane za relewantne. Miarą znaczenia małego ugrupowania jest jego potencjał koalicyjny oraz możliwość wywierania szantażu politycznego. Jest to widoczne na tle dużych partii, w sytuacji gdy małe formacje częstokroć pełnią rolę wsparcia w negocjacjach lub posiadają wkład w kreowaniu nowych standardów kultury politycznej. Z punktu widzenia poparcia, charakterystyczne jest skupianie wokół siebie węższych grup wyborców, rozczarowanych postulatami masowych ugrupowań ${ }^{15}$.

Dlatego też warto przyjrzeć się grupie, którą kojarzy się z elektoratem Ruchu na rzecz Praw i Swobód. Są to mniejszości zamieszkujące Bułgarię, przy czym na potrzeby analizy zostaną przedstawione trzy największe zbiorowości: Turcy, Pomacy i Romowie. Ich wspólnym mianownikiem jest islam ${ }^{16}$. Według spisu powszechnego ludności z $2011 \mathrm{r}$. 577139 obywateli deklaruje się jako muzułmanie, co stanowi odpowiednio ok. 10\% społeczeństwa ${ }^{17}$. Natomiast według raportu autorstwa Pew Research Center wynik ten kształtuje się granicach ok. 920 000, co ma odpowiadać $12,2 \%{ }^{18}$. Jakkolwiek islam jest

${ }^{11}$ Mowa o skandalu związanym z osobą Liutwi Mestana (byłego lidera DPS), który agitował na wiecu wyborczym w języku tureckim. Według bułgarskiego prawa wyborczego kampania powinna odbywać się w języku państwowym, zob. ЦИК глобиха Лютви Местан за агитация на турски език, http://www.economic.bg/bg/news/4/tsik-globi-lyutvi-mestan-za-agitatsiya-na-turski-ezik.html, Портал Economic.bg (dostęp 13.12.2016).

12 A. Chodu bski, Wstęp do badań politologicznych, Gdańsk 2004, s. 126-127.

${ }^{13}$ H. Herzog, Minor Parties: The Relevancy Perspective, „Comparative Politics”, t. 19, nr 3 (1987), s. $317-329$.

${ }_{14}^{14}$ Zob. G. S art or i, Parties and Party Systems, New York 1976.

${ }^{15}$ H. Herzog, Minor..., s. 318.

${ }^{16}$ Zasadniczo w każdym z trzech przypadków deklarowaną religią jest islam. Odstępstwo stanowią Romowie, którzy utożsamiają się częściowo z prawosławiem.

17 Преброяване 2011 (окончателни данни), Национален статистически институт, http://www.nsi.bg/ census2011/ (dostęp 16.12.2016).

${ }^{18}$ Pew Research Center, Mapping the Global Muslim population. A Report on the Size and Distribution of the World's Muslim Population, Washington D.C. 2009, http://www.pewforum.org/2009/10/07/mapping- 
czynnikiem, który łączy Turków, Romów i Pomaków, nie jest on wystarczający, aby objąć wspólną analizą największe mniejszości w Bułgarii ${ }^{19}$. W przypadku każdej z grup będziemy mieć do czynienia z rozbieżnościami w kwestii statusu prawnego, rozmieszczenia i organizacji społecznej.

\section{Turcy}

Według przywoływanego już cenzusu z 2011 r. ${ }^{20}$ liczba Turków zamieszkujących Bułgarię wynosi 588 318. Stanowi to 8,8\% ogółu społeczeństwa. Odnosząc się do polskich badań w tym zakresie, w swoim opracowaniu Anna Parzymies ${ }^{21}$ precyzuje tę wartość na 802 187, chociaż autorka nie podaje źródła wspomnianej informacji. Wracając jednak do samego spisu, struktura wiekowa w obrębie tej grupy przedstawia się następująco:

Wyk. 1. Mniejszość turecka. Struktura wiekowa22

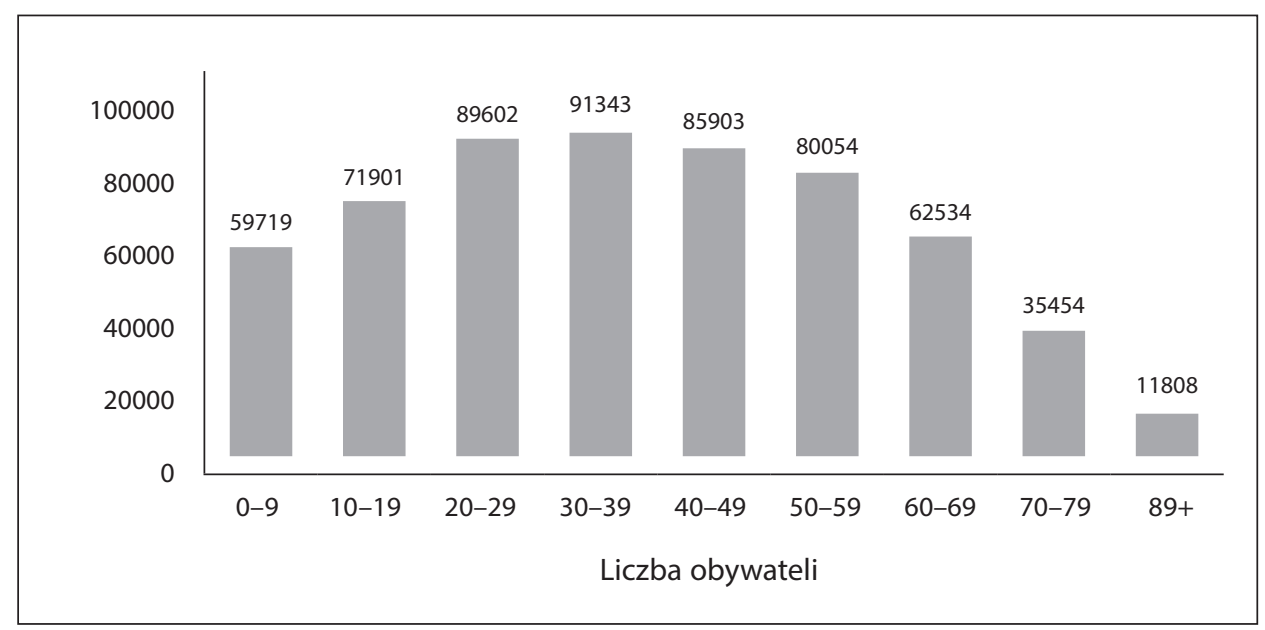

Źródło: Преброяване на населението и жилищния фонд в Република България 2011, Национален Статистически Институт, http://censusresults.nsi.bg/Census/Reports/2/2/R7.aspx (dostęp 24.03.2012).

-the-global-muslim-population/ (dostęp 6.12.2016). Celowo przywołano obydwa źródła, aby zademonstrować, jak wielkie różnice występują pomiędzy oficjalnymi danymi państwa oraz tymi, które pochodzą ze źródeł pozarządowych.

${ }^{19}$ Nie każdy z respondentów zadeklarował się jako wierzący - przyp. autorki.

${ }^{20}$ Преброяване на населението и жилищния фонд в Република България 2011, Национален Статистически Институт, http://censusresults.nsi.bg/Census/Reports/2/2/R7.aspx (dostęp 24.03.2012).

${ }^{21}$ A. Parzymies, Muzutmanie na Bałkanach, [w:] Muzutmanie w Europie, red. eadem, Warszawa 2005 , s. 70 .

${ }^{22}$ Население по местоживеене, възраст и етническа група. Преброяване на населението..., http:// censusresults.nsi.bg/Census/Reports/2/2/R7.aspx (dostęp, 24.11.2016); autorskie opracowanie danych. 
Jak pokazują statystyki, najliczniejszą grupę stanowi ludność w wieku produkcyjnym. Najmniej liczna grupa to ludzie powyżej 80 roku życia - jedynie $11808^{23}$. Kolejny wykres prezentuje stosunek ludności miejskiej do wiejskiej w omawianej grupie etnicznej:

Wyk. 2. Mniejszość turecka. Ludność miejska i wiejska ${ }^{24}$

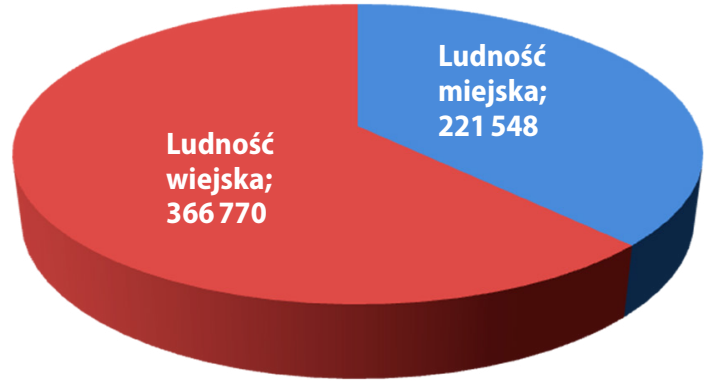

Źródło: Преброяване на населението и жилищния фонд в Република България 2011, Национален Статистически Институт, http://censusresults.nsi.bg/Census/Reports/2/2/R7.aspx (dostęp 24.03.2012).

Z prezentowanego wykresu wynika, że przewagę ma ludność wiejska. Geograficznie wśród regionów, w których etniczni Turcy stanowią znaczącą większość, możemy wymienić: Kyrdżali (86,5 tys./ 130,8 tys.) $)^{25}$, Razgrad (57,3 tys./ 114,5 tys.), Szumen (50,9 tys./ 168 tys.), Burgas (49,4 tys./ 370,5 tys.), Silistra (40,3 tys./ 111,6 tys.), Tyrgowiszte (38,2 tys./ 107 tys.). Powyższe statystyki pokazują, że skupiska ludności tureckiej znajdują się przede wszystkim w północno-wschodniej (Razgrad, Szumen, Silistra, Tyrgowiszte) i południowo-wschodniej Bułgarii (Burgas, Kyrdżali) ${ }^{26}$. Jak zauważa Irena Stawowy-Kawka, Turków można spotkać również w większych miastach, takich jak choćby Sofia, Warna, Ruse czy Płowdiw ${ }^{27}$. Spośrod wszystkich grup muzułmańskich to oni wyróżniają się największą aktywnością w życiu społecznym - mają wydawnictwa, organizują wydarzenia kulturalne, uczestniczą w życiu politycznym ${ }^{28}$.

23 Население по местоживеене, възраст и етническа група. Преброяване на населението..., http:// censusresults.nsi.bg/Census/Reports/2/2/R7.aspx (dostęp 24.03.2012).

${ }^{24}$ Ibidem, http://censusresults.nsi.bg/Census/Reports/2/2/R7.aspx, (dostęp 16.12.2016); autorskie opracowanie danych.

25 Wartości umieszczone w nawiasach oznaczają liczbę etnicznych Turków w stosunku do ogólnej liczby mieszkańców regionu.

${ }^{26}$ Население по местоживеене, възраст и етническа група. Преброяване на населението..., http:// censusresults.nsi.bg/Census/Reports/2/2/R7.aspx, (dostęp, 24.03.2012).

27 I. S taw ow y-K aw ka, Turecka mniejszość narodowa w Butgarii po 1945 r., [w:] Religia a polityka w Europie Południowo-Wschodniej, cz. 1, I. Czamańska, W. Szulc (red.), Poznań 2010, s. 108.

${ }^{28}$ Chociaż założyciele partii Ruch na rzecz Praw i Swobód odcinają się od etnicznych fundamentów ugrupowania, faktem jest, że zostało ono założone przez etnicznych Turków - przyp. autorki. 


\section{Pomacy}

Kolejną znaczącą grupę stanowią Pomacy ${ }^{29}$. Są to muzułmanie żyjący na obszarze południowo-zachodniej Bułgarii i północnej Grecji, posługujący się językiem bułgarskim lub tureckim. Pomimo odrębności kulturowej Pomacy nie są zbyt zorganizowani wewnętrznie, co wielokrotnie wykorzystywały władze poszczególnych państw ${ }^{30}$. Bułgarzy nazywają ich butgaromahometanami (buł. българомахомедани), twierdząc, że przynależą do narodu bułgarskiego, chociaż mieli ulec przymusowej islamizacji w XVII w. Dowodem na to ma być używany przez Pomaków bułgarski. Należy jednak zauważyć, że w istocie jest to dialekt daleko odbiegający od standardu bułgarszczyzny. Z kolei Grecy wnoszą, że to ich kraj jest ojczyzną ludności pomackiej. Powołują się przy tym na śladowe występowanie hellenizmów w dialekcie ${ }^{31}$. Turcy natomiast utrzymują, że to czynnik wspólnej religii powinien decydować w kontekście wyboru tożsamości ${ }^{32}$.

Z drugiej strony Pomacy wielokrotnie spotykali się z niechęcią i dyskryminacją, jak chociażby w latach 1971-1973, kiedy komunistyczne władze Bułgarskiej Republiki Ludowej stosowały wobec nich brutalną politykę asymilacyjną, która zresztą dotknęła także Romów i Tatarów. Nowe uregulowania prawne stwarzały liczne ograniczenia w obszarze życia codziennego (m.in. publiczne użycie języka, ubiór, praktyki religijne). Skrajnym tego wyrazem stała się przymusowa zmiana imion z tureckobrzmiących na bułgarskie ${ }^{33}$. Podobnych represji doświadczyli potem w latach 80 . Turcy ${ }^{34}$. Te wydarzenia pozostawiły swoje piętno. Do dziś znane są przypadki, że ludność pomacka uparcie pozostaje przy zmienionych imionach, co wszakże nie wynika z poczucia bułgarskiej tożsamości narodowej, a raczej z obawy, że czasy odrodzenia narodowego mogłyby powrócić35. Współcześnie liczba Pomaków zamieszkujących Bułgarię wynosi ok. $176687^{36}$. Należy jednak podchodzić do tych danych z dużym dystansem, gdyż wartość przybliżona nie jest przypadkowa w tej kwestii. Jak dotąd żaden spis powszechny w Bułgarii nie uwzględnił Pomaków jako odrębnej mniejszości. Część z nich deklaruje tożsamość bułgarską, pozostali turecką lub romską; niemniej znane są przypadki, gdy nie potwierdzają żadnej z powyższych ${ }^{37}$. Powołując się na opracowanie Alego Eminova, obecnie Pomacy zamiesz-

${ }_{29}$ Warto zauważyć, że określenie „Pomak” samo w sobie nosi negatywne konotacje. Etymologiczne ślady prowadzą w kierunku kultury ludowej, gdzie wiązano tę nazwę ze słowem подмамвам, czyli mamić kogoś, fałszywie obiecywać. Miało to nawiązywać do tradycji, według której Pomacy ulegli obietnicom tureckim i przeszli na islam. W języku bułgarskim używa się raczej określenia Българи мохамедани, [za:] Михаил Арнаудов, Родопски помаци, http://literaturensviat.com/?p=29168 (dostęp 17.12.2016).

${ }^{30}$ A. Em in ov, Turkish and other Muslim Minorities in Bulgaria, Londyn 1997, s. 99.

31 Ibidem, s. 102.

32 Ibidem, s. 103.

33 I. S t a w o w y-K a w k a, Turecka mniejszość narodowa, s. 111.

34 Represje z lat 1984-1985 znane są w historii pod nazwą „procesu odrodzeniowego” (bułg. Възродителен процес). Jednak sam termin odnosi się do szerszej perspektywy historycznej, gdyż jeszcze w roku 1958 Politbiuro wydało tzw. Tezy o pracy wśród ludności tureckiej, które wbrew nazwie odnosiły się do wszystkich muzułmanów [za:] A. Eminov, Turcs and Tatars in Bulgaria and the Balkans, „Nationalites Papers”, t. 28, nr 1, 2000, s. 54.

35 A. Parzy mies, Muzutmanie na Bałkanach, s. 68.

36 Ibidem, s. 70.

${ }^{37}$ Е. Иван о ва, Идентичност и идентичности на помаците в България, http://www.librev.com/-/1516-2012-03-06-09-21-19 (dostęp, 25.03.2012). 
kują góry Rodopy w południowej Bułgarii. Obszar ich osadnictwa rozciąga się od doliny rzeki Mesty na zachodzie, aż do granic regionów Haskowo-Kyrdżali na wschodzie. Małe skupiska ludności pomackiej napotyka się także w okolicach miasta Łowecz ${ }^{38}$.

\section{Romowie}

Ostatnią grupą etniczną omawianą w tym zestawieniu są Romowie. Według statystyk cenzusu liczą 325343 osoby, co odpowiada 4,9\% ogółu ludności Bułgarii ${ }^{39}$. Chociaż w przypadku Romów problem z ustaleniem tożsamości nie jest tak złożony, jak w przypadku Pomaków, tu także dochodzi do nieścisłości. Typowe wśród nich jest deklarowanie narodowości tureckiej lub bułgarskiej - przede wszystkim w zależności od wyznawanej religii. Często muzułmańscy Romowie uznają się za Turków, zaś ci będący chrześcijanami - za Bułgarów ${ }^{40}$.

Wyk. 3. Mniejszość romska. Struktura wiekowa ${ }^{41}$

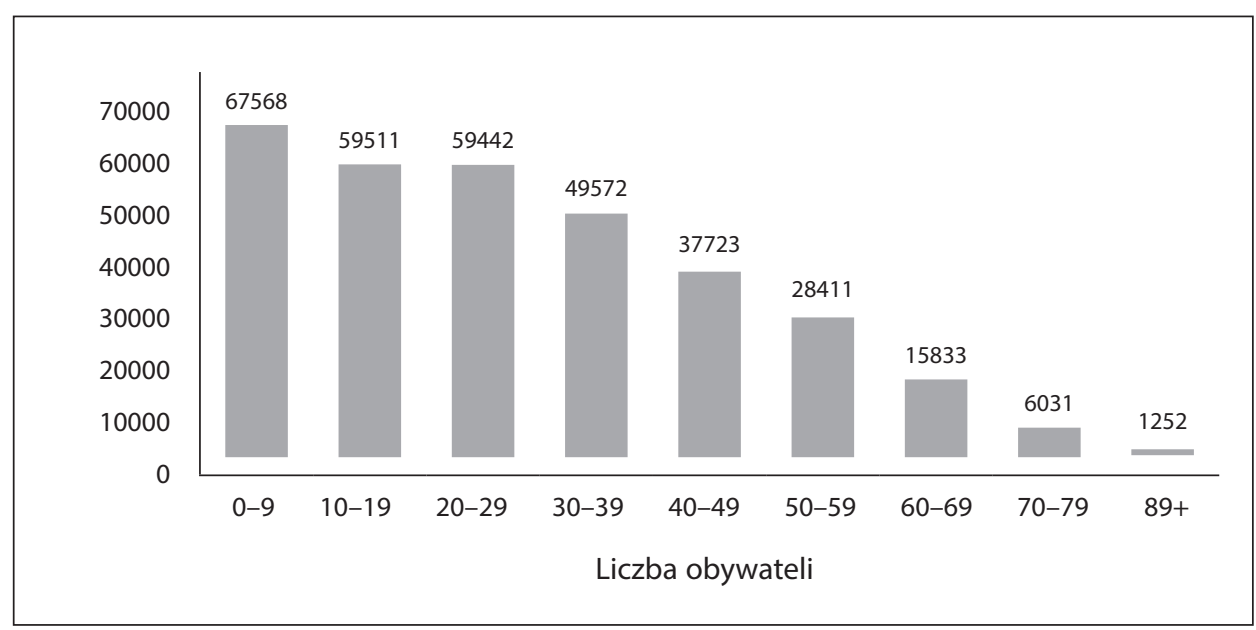

Źródło: Преброяване на населението и жилищния фонд в Република България 2011, Национален Статистически Институт, http://censusresults.nsi.bg/Census/Reports/2/2/R7.aspx (dostęp 24.03.2012).

Według przekazów historycznych Romowie pojawili się po raz pierwszy na ziemiach bułgarskich na długo przed osmańskim podbojem. Po II wojnie światowej, podobnie jak Pomacy i Tatarzy, Romowie nie uniknęli represji ze strony władz komunistycznych. Rom-

\footnotetext{
38 A. Eminov, Turkish and other..., s. 101.

39 Население по местоживеене, възраст и етническа група. Преброяване на населението..., http:// censusresults.nsi.bg/Census/Reports/2/2/R8.aspx (dostęp 25.03.2012).

${ }^{40}$ A. Eminov, Turkish and other..., s. 112.

41 Население по местоживеене, възраст и етническа група. Преброяване на населението..., http:// censusresults.nsi.bg/Census/Reports/2/2/R7.aspx (dostęp 24.11.2016); autorskie opracowanie danych.
} 
scy muzułmanie także doświadczyli przymusowej asymilacji; miało to miejsce w grudniu 1958 r., kiedy światło dzienne ujrzały przepisy dotyczące ograniczania nomadycznego trybu życia Romów. Później zostali zobligowani do zmiany imion i nazwisk na bułgarskie. Jak twierdzi Anna Parzymies, podobno nie odczytywali tego jako osobistej krzywdy i ataku na ich tożsamość ${ }^{42}$. Poniższy wykres przedstawia strukturę wiekową w obrębie mniejszości romskiej.

Analizując wyniki tego wykresu, od razu można zauważyć, że mniejszość romska posiada wysoki przyrost naturalny - w obrębie poszczególnych grup wiekowych dzieci i młodzież stanowią odpowiednio 20,7\% i 18\%. Natomiast w grupie 80+ zarejestrowano jedynie 1252 osoby. Ogólny wniosek, podobnie jak w przypadku mniejszości tureckiej, wskazuje, iż Romowie stanowią młodą społeczność. Kolejny wykres prezentuje stosunek ludności zamieszkującej miasta do ludności wiejskiej.

Wyk. 4. Mniejszość romska. Ludność wiejska i miejska³

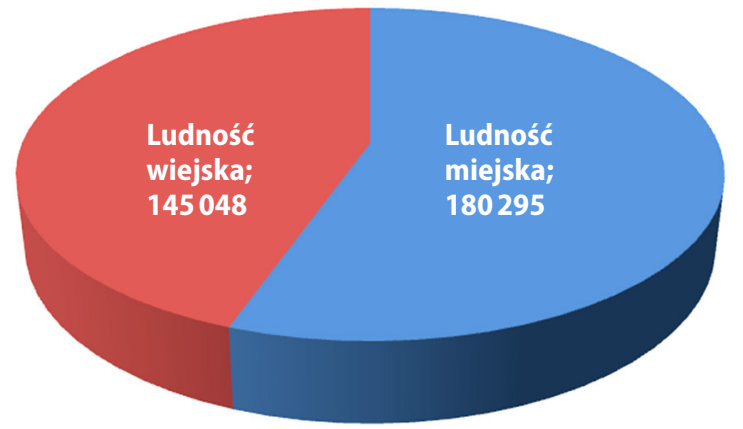

Źródło: Преброяване на населението и жилищния фонд в Република България 2011, Национален Статистически Институт, http://censusresults.nsi.bg/Census/Reports/2/2/R7.aspx (dostęp 24.03.2012).

W odróżnieniu od mniejszości tureckiej, Romowie częściej zamieszkują miasta, jednak ze względu na nomadyczny tryb życia tej grupy, trudno sprecyzować rozmieszczenie geograficzne. Regiony posiadające względnie wysoki odsetek mniejszości romskiej to: Płowdiw (30,2 tys./ 620,3 tys.), Stara Zagora (24 tys./ 308,1 tys.), Pazardżik (20,4 tys./ 246 tys.), Sliwen (20,5 tys./ 173,2 tys.), Montana (18,2 tys./ 143,4 tys.), Sofia (17 tys./ 230,8 tys. $)^{44}$. Od okręgu sofijskiego na zachodzie do sliweńskiego na wschodzie, obszar ten układa się W długi poziomy pas na mapie Bułgarii. W kwestii języków, jakimi posługują się przedstawiciele społeczności romskiej, dane spisu informują o 273 tys. użytkowników języka romani (w różnych wariantach). Na drugiej pozycji znajduje się bułgarski (24 tys.), zaś niedaleko po nim turecki $(21,4 \text { tys. })^{45}$.

42 A. Parzy mies, Muzulmanie na Bałkanach, s. 62.

43 Население по местоживеене, възраст и етническа група. Преброяване на населението..., http:// censusresults.nsi.bg/Census/Reports/2/2/R7.aspx (dostęp 24.11.016); autorskie opracowanie danych.

${ }^{44}$ Ibidem, http://censusresults.nsi.bg/Census/Reports/2/2/R7.aspx (dostęp 26.11.2016).

45 Ibidem, http://censusresults.nsi.bg/Census/Reports/2/2/R8.aspx (dostęp 29.03.2012). 
W 2014 r. agencja Gallup International przeprowadziła sondaż powyborczy, który miał za zadanie nakreślić profil bułgarskich wyborców. Wynika z niego, że chociaż 83,7\% bułgarskich Turków głosuje na DPS, wynik ten w przypadku Romów wynosi jedynie 36,4\%. (22,2\% elektoratu nie określiło swojej przynależności etnicznej). Z kolei tylko 2,1\% Bułgarów głosowało trzy lata temu na to ugrupowanie. Wskazuje to, że nie wszystkie mniejszości upatrują swojego kandydata w Ruchu na rzecz Praw i Swobód. Według badania Romowie oraz Pomacy głosują także na BSP i GERB. Natomiast statystyczny wyborca Ruchu jest w średnim wieku, posiada wykształcenie na poziomie podstawowym, mieszka na wsi, prowadzi gospodarstwo lub nie jest aktywny zawodowo ${ }^{46}$. Jak zostało wspomniane, ogromna część elektoratu zamieszkuje tzw. regiony kompaktowe (bułg. компактни райони), tj. Kyrdżali, Haskowo i Smoljan. Tamtejsza ludność tradycyjnie utrzymuje się z rolnictwa, zwłaszcza z uprawy tytoniu i winorośli. Jeszcze w $2001 \mathrm{r}$. tylko 26\% ogólnej liczby Turków stanowili mieszkańcy miast. Na wsi, gdzie infrastruktura, dostęp do edukacji i opieki zdrowotnej bywały na gorszym poziomie, zjawiska takie jak wysokie bezrobocie tylko pogarszały sytuację mniejszości ${ }^{47}$. Ponieważ rozwiały się złudzenia co do lepszych perspektyw, a poczucie wykluczenia, wzmocnione czynnikiem odmienności etnicznej, stało się dojmujące, powstała idealna nisza, w której Ruch na rzecz Praw i Swobód od lat rozgrywa swoje poparcie.

Wyniki wyborów do Zgromadzenia Narodowego pokazują, że ostatnie lata wypadają korzystnie dla partii Mustafy Karadayi ${ }^{48}$. Jej wyniki, oscylujące na poziomie 14\% poparcia, kształtują liczbę deputowanych wysoko powyżej trzydziestu ${ }^{49}$.

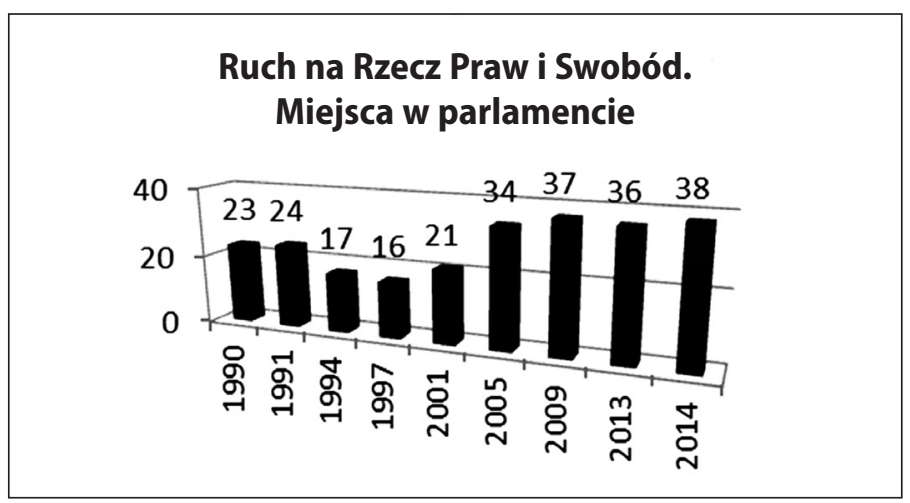

Źródło: opracowanie własne na podstawie biuletynów bułgarskiej Centralnej Komisji Wyborczej [za:] Централна Избирателна Комисия, http://portal.cik.bg/ (dostęp 17.11.2016).

46 Галлъп Интернатионъл, Електорални профили - парламентарни избори 2014, http://www.gallupinternational.bg/bg/\%D0\%9F\%D1\%83\%D0\%B1\%D0\%BB $\%$ D0 $\%$ B8 $\%$ D0 $\%$ BA $\%$ D0 $\%$ B $0 \% \mathrm{D} 1 \% 86 \%$ D0 $\%$ B8 $\%$ D0\%B8/2014/205-Electoral-Profiles-General-Elections-2014, (dostęp 31.12.2016).

${ }^{47}$ L. Petkova, The Ethnic Turks in Bulgaria: Social Integration and Impact on Bulgarian-Turkish Relations 1947-2000, ,The Global Review of Ethnopolitics”, t. 1, nr 4, 2002, s. 44-47.

48 Od 2016 r. Mustafa K a r adayi został nowym liderem DPS - przyp. autorki.

49 Źródło: opracowanie własne na podstawie biuletynów bułgarskiej Centralnej Komisji Wyborczej [za:] Централна Избирателна Комисия, http://portal.cik.bg/ (dostęp 17.11.2016). 
Turcy reprezentują najbardziej zorganizowaną społeczność, dlatego to właśnie oni stanowczo sprzeciwili się represjom ze stron władz komunistycznych. Kiedy w latach 70. milicja i wojsko wkraczały do pomackich wsi, aby przeprowadzać akcję zmiany imion, napotykały na opór mieszkańców górskich wiosek. Jednak dopiero w połowie lat 80. podobna polityka wobec mniejszości tureckiej pokazała, że represje osiągnęły apogeum, a tłumy wyszły na ulice, by protestować. Ruch na rzecz Praw i Swobód jest partią o rodowodzie opozycyjnym. Zanim zaczął funkcjonować jako formacja polityczna, jego czołowi działacze byli skupieni wokół Tureckiego Ruchu Narodowowyzwoleńczego w Bułgarii (bułg. Турско националносвободително движение в България) $)^{50}$, powstałej w 1985 r. podziemnej organizacji, która sprzeciwiała się polityce asymilacji. Celem Ruchu, który działał tylko przez rok, zanim bułgarska służba bezpieczeństwa ją rozbiła, było przede wszystkim nagłośnienie problemu poza granicami Bułgarskiej Republiki Ludowej, agitacja wśród społeczeństwa oraz organizowanie pokojowych manifestacji. Wówczas rolę czołowego ideologa Ruchu odgrywał doktor filozofii Uniwerystetu Sofijskiego, Ahmed Dogan ${ }^{51}$. Główną intencją Dogana było pokojowe zażegnanie kryzysu pomiędzy władzami a represjonowaną ludnością muzułmańską. Jego działalność nie trwała jednak długo, gdyż na wiosnę 1985 r. został skazany na karę więzienia, w którym przebywał do maja 1989 r. ${ }^{52}$ Tymczasem reszta działaczy skupiła się wokół innych organizacji. Nie brakowało wśród nich i radykalnych formacji, które zajmowały się dywersją, a nawet atakami terrorystycznymi. Najgłośniejszą z akcji było wysadzenie wagonu kolejowego na stacji Bunowo; wówczas śmierć poniosło siedem osób, w tym dzieci ${ }^{53}$. W dalszej perspektywie są to zarzuty, które szkodzą wizerunkowi partii, chociaż jej niewątpliwym sukcesem jest budowanie swojego potencjału wokół opozycyjnej legendy. Kluczowe miejsce w jej centrum zajmuje postać Ahmeda Dogana, polityka o wyjątkowym autorytecie, który stworzył ugrupowanie i kierował nim przez ponad 20 lat $^{54}$. Nawet gdy w 1994 r. opinią publiczną wstrząsnęły pogłoski o jego współpracy ze służbą bezpieczeństwa, lider Ruchu zdołał zachować pełnioną funkcję $e^{55}$. Małe partie, których struktura opiera się na charyzmatycznym przywództwie, mają szansę na wzmocnienie swojej roli w systemie partyjnym ${ }^{56}$.

Oskarżeniem, które wciąż jest kierowane pod adresem DPS, jest wspomniany etniczny charakter partii. W 1992 r. 93 deputowanych Zgromadzenia Narodowego, powołując się na dwa konstytucyjne zapisy, wniosło do Sądu Konstytucyjnego skargę, w której domagali się uznania rejestracji partii politycznej Ruch na rzecz Praw i Swobód (z 26 kwietnia 1990 r.) za niezgodną z konstytucją. W zarzutach nawiązywano do następujących zapisów w Konstytucji:

${ }^{50}$ I. S t aw ow y-K aw k a, Islam and Politics: the Case of Bulgaria, [w:] Religia a wspótczesne stosunki międzynarodowe, B. Bednarczyk, Z. Pasek, P. Stawiński (red.), Kraków 2010, s. 55-56.

51 С. Ки с ел и нов ски, И. С т а в в и-Кав ка, Малцинствата на Балканот (20 век), Скопје 2004, s. $146-149$.

${ }^{52}$ Bozhidar Z a h a ri e v, The Treatment of Ethnic Turks by the Bulgarian Communist Party and their Status Quo, Sofia 2003, s. 31.

53 M. Mahon, The Turkish minority under Communist Bulgaria - politics of ethnicity and power, ,Journal of Southern Europe and the Balkans", t. 1, nr 2, s. 158.

${ }^{54}$ Ahmed Dogan kierował DPS do 2013 r. Następnie zajął miejsce honorowego przewodniczącego Ruchu.

55 R. Woźnic a, Bułgarska polityka..., s. 81.

${ }_{56}$ H. Herzog, Minor Parties..., s. 324. 
11.4: Nie można tworzyć partii politycznych na podstawie przynależności etnicznej, rasowej lub wyznaniowej, jak również partii, które stawiają sobie za cel siłowe przejęcie władzy państwowej ${ }^{57}$.

44.2: Zabronione są organizacje, których działalność skierowana jest przeciwko suwerenności, integralności terytorialnej kraju i jedności narodu, na rzecz wzniecania wrogości rasowej, narodowej, etnicznej lub religijnej, naruszania praw i wolności obywateli, jak również organizacje, które tworzą tajne lub paramilitarne struktury lub dążą do osiągnięcia swoich celów drogą przemocy ${ }^{58}$.

Jednak sąd wyrokiem z 21 kwietnia 1992 r. odrzucił wniosek, kontrargumentując, że nie można upatrywać fundamentów DPS w etnicznym bądź religijnym profilu jej założycieli, gdyż na tej samej zasadzie państwo powinno zabronić aktywności partiom o profilu chrześcijańsko-demokratycznym lub narodowym, reprezentującym ludność etnicznie bułgarską. Pomimo przewagi obywateli pochodzenia tureckiego wśród polityków Ruchu funkcjonowali również działacze bułgarscy. W kontekście art. 44.2 sąd zauważył, że brak dowodów w postaci indywidualnych wyroków karnych, które mogłyby potwierdzić zasadność skargi w tej sprawie ${ }^{59}$.

Orzeczenie z 1992 r. stało się momentem przełomowym dla Ruchu na rzecz Praw i Swobód. Polityczna metamorfoza, zwłaszcza w sferze programu oraz obietnic wyborczych, stała się koniecznością. Etapy tej przemiany trafnie pokazują nagłówki gazety partyjnej „Prawa i Swobody” (bułg. „Права и свободи”), wydawanej od 11 lutego 1991 r. do 29 grudnia 1995 r. W tej redagowanej w języku bułgarskim i tureckim gazecie Ruch publikował dokumenty partyjne, felietony polityczne, ale również reportaże oraz artykuły o tematyce kulturalnej. Za przykład ilustrujący metamorfozę programową posłuży analiza wybranych nagłówków pisma. Na początku 1991 r. nierzadko pojawiały się takie tytuły, jak: Język ojczysty - w domowym areszcie? (bułg. Майчиният езикв домашен арест?), Proces odrodzeniowy to przestepstwo zwane ludobójstwem (butg. Възродителен процес е престъпление наречено геноцид), Bezdomni w doти... (bułg. Бездомници у дома...), Pogrom nad meczetami (bułg. Погром над джамии) itp ${ }^{60}$. Wskazują one na zaniepokojenie partii położeniem mniejszości tureckiej. Nie brak nawiązań do polityki przymusowej asymilacji, jej dramatycznych skutków oraz biernej postawy rządzących, co pokazuje często pojawiającą się tendencję wśród małych partii politycznych, które nie stawiają sobie za cel wygranej, a raczej starają się przyciągnąć uwagę opinii publicznej ${ }^{61}$. Na początku Ruch na rzecz Praw i Swobód otwarcie demonstrował swoje niezadowolenie z przebiegu zmian ustrojowych w Bułgarii. Uważano, że Turcy jako grupa społeczna są ignorowani przez nowe władze. Brak konsekwencji wobec winnych tzw. procesu odrodzeniowego oraz krzywdząca dla mniejszości tureckiej ustawa

\footnotetext{
${ }^{57}$ Art. 11.4, Konstytucja Republiki Bułgarii w dniu 12 lipca 1991, http://libr.sejm.gov.pl/tek01/txt/konst/ bulgaria2011.html (dostęp, 07.06.2017).

${ }_{58}$ Art.44.2, Konstytucja Republiki Bułgarii w dniu 12 lipca 1991, http://libr.sejm.gov.pl/tek01/txt/konst/ bulgaria2011.html (dostęp, 07.06.2017).

59 Решение от 21 април 1992г., Конституционен съд на Република България, http://www.intera-x.com/ constcourt/Pages/Document/default.aspx?ID=33 (dostęp 31.12.2016).

60 „Права и свободи”, t. 1-2 (1991).

${ }^{61}$ H. Herzog, Minor parties..., s. 321.
} 
o reprywatyzacji ziemi zdawały się potwierdzać ten status ${ }^{62}$. Skromna reprezentacja DPS w parlamencie bułgarskim w tamtym czasie nie pozwalała wprawdzie realnie sprawować władzy, otwierała jednak możliwość dyskusji na temat położenia mniejszości tureckiej w demokratycznym państwie.

Późniejsze numery pisma, począwszy od 1992 r., w sposób widoczny operują spokojniejszą retoryką, cechującą się wolą dialogu i mediacji: Przestrzeganie praw mniejszości etnicznych - warunkiem pokoju i bezpieczeństwa (bułg. Спазването на правата на етническите малцинства - условие за мир и сигурност), DPS jest i będzie uniwersalna organizacja wszystkich bułgarskich obywateli (bułg. ДПС е и ще бъдде универсална организачия на всички български граждани), Butgaria jest przyktadem wspótistnienia różnych etnicznych i religijnych społeczności. Działalność DPS jest decydujacym czynnikiem zmniejszajacym społeczne napięcie (bułg. България е пример за съжителство на различните етнически и религиозни общности. Дейността на ДПС е решаваш, фактор за намаляване на социиално напрежение) ${ }^{63}$. Tym razem Ruch na rzecz Praw i Swobód podkreśla inne cele. Dominują odwołania do pokoju, bezpieczeństwa wewnętrznego czy napięcia etnicznego. Niewątpliwie jest to echem ówczesnej sytuacji w regionie, czyli wojny w Jugosławii. Lokalny konflikt również wywarł wpływ na przemiany w DPS. Wątek jugosłowiański był nader często wykorzystywany przez partię, aby utwierdzić jej rolę na bułgarskiej scenie politycznej:

(...)Wspólnymi siłami osiągnęliśmy tak zwany bułgarski model, który posłużył na etapie transformacji ustrojowej w rozwiązywaniu problemów etnicznych w państwie. Będziemy to kontynuować, aby zakorzenić ten model i nie dopuścimy choćby do warunków, które zbliżyłyby Bułgarię do tego, co stało się w Bośni ${ }^{64}$.

Ten fragment przemówienia zawiera także inny ważny element retoryki Ruchu na rzecz Praw i Swobód: przypisanie sobie głównej roli w umacnianiu tzw. bułgarskiego modelu etnicznego (bułg. Български етнически модел). Jest to swego rodzaju słowo-klucz bułgarskiej polityki po 1989 roku. Bułgarski model etniczny oznacza zjawisko pokojowego współistnienia różnorodnych kultur (etnicznych, religijnych, językowych) oraz ich wzajemne przenikanie się na gruncie bułgarskim ${ }^{65}$. Nieprecyzyjna natura tego zagadnienia sprawiła, że badacze niekiedy odwołują się do niego z dużą nieufnością. O tej niejednorodności pisze Iskra Baewa:

(...) współczesne rozumienie „modelu etnicznego” w Bułgarii z jednej strony jest niezwykle wąskie, a z drugiej przesadnie zależne od często zmieniającej się koniunktury politycznej ${ }^{66}$.

${ }^{62}$ M. Ż m i g ro d z k i, Przeobrażenia polityczno-ustrojowe i sąd konstytucyjny w Bułgarii, Lublin 1997, s. 95.

63 „Права и свободи”, t. 5-6 (1992/1993).

64 W oryginale: „(...)С общи услия постигнахме тъй наречения български модел за преходния етап и за решаването на етническите проблеми в страната. Ние ще продължаваме да остояваме този модел и няма да допуснем дори условия за босенския вариант в Република България" [za:] А. Д о г а н, Заключително тържествено заседание, [w:] По образ и подобие на европейските измерения. Избрани речи 1991-2008, София 2008, s. 22.

${ }_{65}$ М. Т ах и р, Към интегриращча идентичност, София 2011, s. 123.

${ }^{66}$ И. Б а е в а, Последниците от ,, възродителния процес ” и,,български етнически модел”, [w:] М. Мизов (red.), Българският етнически модел - политическа митологема или проблемна реалност, София 2011, s. 65. 
Nie jest to zatem ani model teoretyczny, ani element oficjalnej doktryny. Jednak od lat 90. jest stałym pojęciem, obecnym w deklaracjach i wypowiedziach polityków. Z tą różnicą jednak, że Ruch widzi się w roli architekta tej koncepcji, odwołując się do niej jak do skutecznego lekarstwa na problemy społeczne. Kolejnym czynnikiem, który kształtuje współczesny wizerunek partii, jest walka o prawa człowieka. DPS ogłasza się reprezentantem wszystkich obywateli, których prawa są łamane, twierdząc, że jako partia posiada moralne prawo i obowiązek ich obrony:

(...)Ruch na Rzecz Praw i Swobód pojawił się jako efekt łamania podstawowych praw człowieka i dlatego właśnie w swej istocie jest polityczną formacją liberalną ${ }^{67}$.

W końcu niezwykle ważnym celem ugrupowania stało się zbliżanie Bułgarii do struktur euroatlantyckich i UE. DPS uznaje swój wielki wkład w dzieło integracji europejskiej:

(...)Rządząca liberalna koalicja NDSV-DPS przeniosła bezpieczeństwo narodowe w orbitę systemu zbiorowego bezpieczeństwa NATO. To rząd NDSV-DPS doprowadził kraj do wrót UE ${ }^{68}$.

Powyższy fragment nawiązuje do czasów, kiedy Ruch był koalicjantem w rządzie cara Symeona Sakskoburggotskiego, co niewątpliwie należy odebrać jako wyraźny sygnał, że partia Ahmeda Dogana przez lata umocniła swój potencjał ${ }^{69}$, by brać udział w procesie decydowania politycznego. W statucie z 2007 r. można odnaleźć m.in. takie cele jak: wzmacnianie pozycji państwa w oparciu o współpracę międzynarodową, dostęp Bułgarii do struktur UE i NATO oraz utrzymanie pokoju i wzajemnego zrozumienia w całym regionie. Następnie dokument precyzuje, że Ruch będzie realizował powyższe postulaty przez aktywne uczestnictwo w pracach parlamentu i rządu, współpracę ze wszystkimi partiami politycznymi oraz organizacjami międzynarodowymi ${ }^{70}$. W odniesieniu do teorii relewancji DPS spełnia kryterium potencjału koalicyjnego, jest zatem partią mającą znaczenie w bułgarskim systemie politycznym.

Według typologii, którą wprowadzili Joseph Rudolf i Robert Thompson, można wyróżnić kilka rodzajów ruchów o profilu etnicznym w zależności od celów, do których dążą te formacje:

1. Partie nastawione na wyniki (output-oriented parties)

2. Partie antyautorytarne (anti-authority parties)

3. Partie antyrządowe (anti-regime parties)

4. Partie antyspołecznościowe (anti-community parties) ${ }^{71}$.

${ }^{67} \mathrm{~W}$ oryginale: „(...) Движението за права и свободи възникна като резултат от погазването на основните права на човека и затова в същността си е либерална политическа формация” [za:] А. До ган, По образ..., s. 151.

${ }^{68}$ W oryginale: „(...) Управляваща либерална коалиция на НДСВ-ДПС изведе националната сигурност в орбитата на колективната сигурност на НАТО. Правителството на НДСВ-ДПС придвижи страната ни до вратите на EC" [za:] Ibidem, s. 108.

${ }^{69}$ Wcześniej DPS poparło rząd mniejszościowy Filipa Dimitrowa - przyp. autorki.

${ }^{70}$ Movement for Rights and Freedoms, Status of MRF from 2007, Archive site of MRF, https://web. archive.org/web/20090429195146/http://www.dps.bg/cgi-bin/e-cms/vis/vis.pl?s=001\&p=0413\&n=000004\&g= (dostęp 13.06.2017).

${ }_{71}$ J. R. Rud olph, R. J. Thomps on, Ethnoterritorial Movements and the Policy Process, „Comparative Politics", t. 17, nr 3, 1985, s. 291-311. 
Aktualnie Ruch na rzecz Praw i Swobód najbardziej wpasowuje się w typ partii nastawionej na wyniki. Ruch nigdy nie miał ambicji, by sięgać po władzę. Partia założona przez Ahmeda Dogana to ugrupowanie ugodowe, którego jedynym zamiarem było utrzymanie reprezentacji w parlamencie, niezależnie od tego, kto aktualnie sprawował rządy. U progu przemian ustrojowych w Bułgarii miejsce w Zgromadzeniu Narodowym służyło partii, aby zwrócić uwagę na położenie bułgarskich Turków. Jednak z biegiem lat utrzymywanie tego wizerunku stało się ryzykowne dla DPS, gdyż żadna z partii nie brała pod uwagę koalicyjnej współpracy z ugrupowaniem o profilu etnicznym, a to z kolei skłoniło Ruch, aby stopniowo rozszerzyć swoje priorytety i dzięki temu zwiększyć swój potencjał.

Czytając przemówienie Junala Lutwi przywołane na początku niniejszego artykułu, można odnieść wrażenie, że partia od lat niezmiennie podąża drogą tych samych wartości i ambicji. Biorąc pod uwagę wszystkie wydarzenia i kontrowersje, które ukształtowały tę formację, owo stwierdzenie można odebrać jako co najmniej nieprawdopodobne. Szczególnie w sytuacji, gdy mamy do czynienia z partią w dalszym ciągu oskarżaną o reprezentowanie interesów konkretnego elektoratu. Obserwując wyniki wyborów, wydaje się jasne, że ewolucja programowa nie była konieczna, aby utrzymać lub zwiększyć poziom poparcia, ponieważ w warunkach gdy brakuje poważnych konkurentów ${ }^{72}$, zdaje się ono wciąż niezagrożone. Powodem, który uczynił z Ruchu na rzecz Praw i Swobód partię liberalną, była niestabilność bułgarskiego systemu partyjnego oraz koniunkturalny charakter tej siły politycznej.

\section{Bibliografia}

Źródła publikowane:

Konstytucja Republiki Bułgarii w dniu 12 lipca 1991, http://libr.sejm.gov.pl/tek01/txt/konst/bulgaria2011.html (dostęp, 07.06.2017)

Конституционен съд на Република България, Решение от 21 април 19921992 г., http://www. intera-X.com/constcourt/Pages/Document/default.aspx?ID=33 (dostęp 31.12.2016).

Przemówienia i wspomnienia:

Доган А., По образ и подобие на европейските измерения. Избрани речи 1991-2008, София 2008.

Изказване на Юнал Лютви от 24.04.2016, За ДПС, Движение за права и свободи - официален сайт, http://www.dps.bg/bg/za-dps/ix-ta-nk-na-dps.html (dostęp 11.12.2016).

Raporty:

Pew Research Center, Mapping the Global Muslim population. A Report on the Size and Distribution of the World's Muslim Population, Washington D.C. 2009, http://www.pewforum. org/2009/10/07/mapping-the-global-muslim-population/ (dostęp 6.12.2016).

Галльп Интернатионъл, Електорални профили - парламентарни избори 2014, http://www. gallup-international.bg/bg/\%D0\%9F\%D1\%83\%D0\%B1\%D0\%BB $\% \mathrm{D} 0 \% \mathrm{~B} 8 \% \mathrm{D} 0 \% \mathrm{BA} \% \mathrm{D} 0 \%$

${ }^{72} \mathrm{~W}$ obecnej chwili trudno brać pod uwagę konkurencję ze strony Ludowej Partii Wolność i Godność (НПСД, Народна Партия Свобода и Достойноство) oraz partii Demokratów Odpowiedzialności, Wolności i Tolerancji (ДОСТ, Демократи за отговорност, свобода и толерантност). Są to ugrupowania stosunkowo młode i bez większego znaczenia politycznego. Obydwa powstały jako efekt odejścia z DPS dwóch czołowych postaci: Kasima Dala oraz Liutwi Mestana - przyp. autorki. 
B0\%D1\%86\%D0\%B8\%D0\%B8/2014/205-Electoral-Profiles-General-Elections-2014, (dostęp 31.12.2016).

Национален статистически институт, Преброяване 2011 (окончателни данни), http:/www.nsi. bg/census2011/ (dostęp 16.12.2016).

Национален Статистически Инстьтут, Преброяване на населението и жилищния фонд в Република България 2011, http://censusresults.nsi.bg/Census/Reports/2/2/R7.aspx (dostęp 24.03.2012).

Централна Избирателна Комисия, Бюлетини от парламентарни избори, http://portal.cik.bg (dostęp 17.11.2016).

Monografie:

Eminov A., Turkish and other Muslim Minorities in Bulgaria, London 1997.

Ishiyama J. T., Breuning M., Ethnopolitics in the New Europe, Lynne 1998.

Karp J., Grzybowski M., System konstytucyjny Butgarii, Warszawa 2002.

Parzymies A., Muzułmanie w Europie, Warszawa 2005.

Sartori G., Parties and Party Systems, New York 1976.

Woźnica R., Bułgarska polityka wewnętrzna a proces integracji z Unią Europejska, Kraków 2012. Żmigrodzki M., Przeobrażenia polityczno-ustrojowe i sąd konstytucyjny w Butgarii, Lublin 1997.

Киселиновски С., Ставови-Кавка И., Малцинствата на Балканот (20 век), Скопје 2004.

Тахир М., Към интегриращуа идентичност, София 2011.

Artykuły:

Eminov A., Turcs and Tatars in Bulgaria and the Balkans, „Nationalites Papers”, t. 28, nr 1, 2000.

H. Herzog, Minor Parties: The Relevancy Perspective, „Comparative Politics”, t. 19, nr 3, 1987.

Mahon M., The Turkish minority under Communist Bulgaria - politics of ethnicity and power, „Journal of Southern Europe and the Balkans”, t. 1, nr 2.

Petkova L., The Ethnic Turks in Bulgaria: Social Integration and Impact on Bulgarian-Turkish Relations 1947-2000, „The Global Review of Ethnopolitics”, t. 1, nr 4, 2002.

Stawowy-Kawka I., Islam and Politics: the Case of Bulgaria, [w:] Religia a wspótczesne stosunki międzynarodowe, B. Bednarczyk, Z. Pasek, P. Stawiński (red.), Kraków 2010.

Stawowy-Kawka I., Turecka mniejszość narodowa w Bułgarii po 1945 r., [w:] Religia a polityka w Europie Poludniowo-Wschodniej, cz. 1, I. Czamańska, W. Szulc (red.), Poznań 2010.

Rudolph J. R., Thompson R. J., Ethnoterritorial Movements and the Policy Process, „Comparative Politics", t. 17, nr 3, 1985.

Zahariev B., The Treatment of Ethnic Turks by the Bulgarian Communist Party and their Status Quo, Sofia 2003.

Арнаудов М., Родопски помаци, http://literaturensviat.com/?p=29168 (dostęp 17.12.2016).

Баева И., Българските турии в годините на прехода (1989-2007), [w:] Толерантният националист. Паметен сборник от приятелите на Стайко Трифонов, София 2009.

Баева И., Последниичте от „възродителния процес” и „български етнически модел”, [w:] М. Мизов (red.), Българският етнически модел - политическа митологема или проблемна реалност, София 2011.

Źródła internetowe:

Василева Е., Атентатите в България от началото на 20 век до днес, Днес.бг, http://www.dnes. bg/bulgaria/2012/07/19/atentatite-v-bylgariia-ot-nachaloto-na-20-vek-do-dnes.164276 (dostęp 31.12.2016).

Економик.бг, ЦИК глобиха Лютви Местан за агитация на турски език, http://www.economic. bg/bg/news/4/tsik-globi-lyutvi-mestan-za-agitatsiya-na-turski-ezik.html, „Портал Еconomic. bg" (dostęp 13.12.2016). 
Иванова Е., Идентичност и идентичности на помаците в България, Либрев, http://www.librev. com/--/1516-2012-03-06-09-21-19 (dostęp, 25.03.2012).

Христова И., ДПС доказва, че е турска партия, „Десант”, http://www.desant.net/show-news/34612/ (dostęp 05.01.2017).

Archive site of MRF, https://web.archive.org/web/20090429195146/http://www.dps.bg/cgi-bin/e-cms/vis/vis.pl? $=001 \& p=0413 \& n=000004 \& g=,($ dostęp, 13.06.2017)

Prasa:

Движение за Права и Свободи, „Права и свободи”, t. 1-2 (1991).

Движение за Права и Свободи, „Права и свободи”, t. 5-6 (1992/1993).

\section{Katarzyna Fijołek}

\section{Movement for Rights and Freedoms in Bulgaria. Between the Liberal party and Turkish minority interests' faction}

\section{Summary}

The aim of this paper is to outline how the Movement for Rights and Freedoms (MRF) in Bulgaria has evolved. The party was founded in 1990 by Ahmed Dogan and started as the first political representation of Bulgarian Turks. After more than 25 years in Bulgarian political life, MRF is still arousing controversy. Regarding Article 11.4 of Bulgarian Constitution which bans political parties formed on ethnic, racial and religious lines, MRF seems to be likely anti-constitutional and illegal. However, the MRF politicians' statements and the statute clearly show that the party prefers to be perceived as "all Bulgarian citizens' political force" - liberal and European-oriented, over the years it still doesn't look clear what the nature of MRF is.

Keywords: Turkish minority, MRF, Movements for Rights and Freedoms, ethnic party, liberal party, relevance of parties, minor parties. 